\title{
PEMBENTUKAN KARAKTER ANAK MELALUI PELATIHAN PARENTING DI DESA KAUMAN KECAMATAN SEDAYU KABUPATEN GRESIK
}

\author{
I Wayan Arsana, Irnawati, Suyono \\ Universitas PGRI Adi Buana Surabaya \\ iwayanarsana@unipasby.ac.id
}

\begin{abstract}
The formation of a child's character is not just born, there is a process through which the process becomes an inherent character in a child. This activity aims to provide understanding, education and describe the importance of character building through parenting training for parents, and the community in general around the village of Kuman, Sedayu District, Gresik Regency. The design used in community service uses the pretest posttest design. The implementation of this activity uses the Audio visual learning method and the lecture and demonstration learning method. The number of participants in this activity was 37 participants. Before the start of the activity, which consisted of 3 training sessions, the participants were put in an initial test to do the questions. This is done aiming to find out the participants' initial knowledge about Parenting. Based on the results of the series of activities it can be concluded that the participants' understanding of parenting increased. The value of the increase can be seen from the percentage of pree test and post test scores of participants who initially got the correct answer from the pree test score only $42 \%$ of all participants, to the post test score that answered correctly $88 \%$ of all participants who answered right.
\end{abstract}

Keywords: Parenting, Character, Parents

\begin{abstract}
Abstrak
Pembentukan karakter anak tidaklah lahir begitu saja, ada proses yang dilewatinya sehingga proses tersebut pun menjadi karakter yang melekat dalam diri seorang anak. Kegiatan ini bertujuan untuk memberikan pemahaman, pendidikan dan mendeskripsikan pentingnya pembentukan karakter melalui pelatihan parenting bagi orang tua, dan masyarakat pada umumnya sekita desa Kuman Kecamatan Sedayu Kabupaten Gresik. Desain yang digunakan dalam pengabdian masyarakat ini menggunakan pretest posttest design. Pelaksanaan dalam kegiatan ini menggunakan metode pembelajaran Audio visual dan metode pembelajaran ceramah dan demostrasi. Jumlah peserta dalam kegiatan ini sebanyak 37 peserta. Sebelum dimulainya kegiatan, yang terdiri dari 3 sesi pelatihan, peserta terlebuh dahulu di berlakukan tes awal mengerjakan soal. Hal ini dilakukan bertujuan untuk mengetahuhi pengetahuan awal peserta tentang Parenting. Berdasarkan hasil dari rangkaian kegiatan dapat ditarik kesimpulan bahwa pemahaman peserta tentang parenting meningkat. Adapun nilai peningkatan tersebut dapat dilihat dari prosentase nilai pree test dan post test peserta yang mulanya nilai yang menjawab benar dari nilai pree test hanya $42 \%$ dari seluruh peserta, menjadi nilai post test yang menjawab benar $88 \%$ dari semua peserta yang menjawab benar.
\end{abstract}

Kata Kunci: Parenting, Karakter, Orang Tua

\begin{tabular}{l|l|l} 
Submitted: $2020-07-15$ & Revised: $2020-07-22$ & Accepted: $2020-07-24$
\end{tabular}




\section{Pendahuluan}

Menghadapi rancana pembangunan jangka panjang, sektor sumber daya manusia perlu mendapat perhatian khusus dalam kaitannya dengan usaha meningkatkan kualitas hidup warga bangsa. Sumber Daya Manusia (SDM) merupakan salah satu faktor penting dalam pembangunan suatu bangsa. Dalam hal ini, pemerintah harus memfokuskan untuk mewujudkan sumber daya manusia yang berkualitas. Untuk mewujudkan mewujudkan sumber daya manusia yang berkualitas dapat diwujudkan melalui bidang pendidikan, dan pendidikan anak yang memjadi cikal bakal pembentukan manusia yang berkuliatas harus menjadi perhatian dan fokus pemerintah. Apabila anak mendapatkan pendidikan dengan baik, emungkinan akan menjadi generasi yang hebat dikemudian hari. Pendidikan tersebut tidak hanya sebatas pendidikan yang sifatnya formal (sekolah), namun juga non formal seperti pola asuh anak dalam lingkungan keluarga.

Pendidikan dalam lingkungan keluarga merupakan pendidikan pertama dan utama bagi seorang anak. Pertama karena keluarga (orang tua) adalah orang pertama dan paling banyak melakukan kontak dengan anaknya. Utama karena hasil pengasuhan dan pola pendidikan keluarga memberikan pengaruh amat mendasar bagi perkembangan karakter anak sepanjang kehidupannya. Pendidikan dalam lingkungan keluarga merupakan pendidikan pertama dan utama bagi seorang anak. Pertama karena keluarga (orang tua) adalah orang pertama dan paling banyak melakukan kontak dengan anaknya. Utama karena hasil pengasuhan dan pola pendidikan keluarga memberikan pengaruh amat mendasar bagi perkembangan karakter anak sepanjang kehidupannya (Tafsir dkk, $2002: 8$ ).

Keluarga merupakan lingkungan pertama dan utama yang dialami oleh seorang anak. Keluarga merupakan lingkungan awal dan memiliki peran strategis dalam mendukung penyeleggaraan pendidikan bagi anak. Generasi yang unggul akan tercipta apabila diterapkan pola asuh yang benar. Dalam situasi ini, orang tua memegang peranan utama dalam proses pembelajaran anak - anaknya, terutama dikala mereka belum dewasa (Lestari, 2008). Baik dan tidak tumbuh kembang seorang anak juga tergantung dari pola asuh, asah, dan asih seluruh anggota keluarga terutama orang tua, oleh karena itu keluarga merupakan tempat yang tepat dalam mendidik anak. Keluarga juga menjadi tempat mengajarkan nilai-nilai dan tingkah laku dan kepribadian yang yang sesuai dengan norma-norma dalam masyarakat. Nilai-niali tersebut sebagai contoh: nilai tanggung jawab, menghargai, menghormati, dan lain sebagainya. Keluarga juga berperan penting dalam pembentukan karakter anak. Pembentukan karakter anak tidaklah lahir begitu saja, ada proses yang dilewatinya sehingga proses tersebut pun menjadi karakter yang melekat dalam diri seorang anak. Sebagai orangtua, tanpa disadari, sikap orang tua yang negatif pada anaknya pun justru akan menjatuhkan anak tersebut. Misalnya, ketika orang tua memukul dan memberikan tekanan yang menjadikan anak bersikap negatif, rendah diri, minder, penakut, dan tidak berani mengambil resiko, yang di mana karakter-karakter tersebut akan dibawanya sampai ia dewasa (Prasanti \& Fitriani, 2018).

Anak akan cenderung melakukan sesuatu berdasarkan apa yang dilihat, didengar, dan dialaminya. Sikap suka meniru yang dimiliki anak, dengan didorong oleh rasa ingin mencoba sesuatu yang diminatinya, membuat anak meniru secara spontan tanpa 
mempertimbangkan baik atau buruknya (Arifuddin, 2009 : 99). Untuk itu, segala sesuatu yang terjadi dalam keluarga, akan mempengaruhi karakter dan kebiasaan anak. Pendidikan anak dalam keluarga harus ditopang dengan keteladanan dan pembiasaan yang benar. Dan orang tua menjadi tolak ukur dalam menentukan berhasil tidaknya orang tua dalam mendidik anak. Menurut Jhonson (1988) peranan keluarga menggambarkan seperangkat perilaku antar pribadi, sifat, kegiatan yang berhubungan dengan pribadi dalam posisi dan situasi tertentu. Peranan pribadi dalam keluarga didasari oleh harapan dan pola perilaku dari keluarga, kelompok dan masyarakat. Orang tua adalah orang yang pertama dikenal anak.

Proses pembentukan karakter anak usia dini juga meliputi faktor keluarga, sekolah, dan komunitas. Ketika berbicara mengenai pembentukan karakter anak usia dini, kita menjadi teringat pada faktor lingkungan dan keluarga yang berada dekat dengan anak tersebut (Prasanti \& Fitriani, 2018). karakter itu sendiri dimaknai sebagai ciri khas setiap individu berkenaan dengan jati dirinya yang merupakan kualitas batiniah, cara berpikir dan berperilaku untuk hidup dan bekerja sama, baik dalam lingkup keluarga, masyarakat, bangsa dan negara (Maksudin; 2013 : 3). Sedangkan Karakter menurut Aqib (2011 : 30) sebagai aktualisasi potensi dari dalam dan internalisasi nilai-nilai moral dari luar menjadi bagian dari kepribadiannya.

Pendidikan karakter harus ditanamkan sejak anak masih kecil dan melalui proses yang disesuaikan dalam tahapan perkembangan anak. Hal ini menunjukkan bahwa dalam pembentukan karakter anak dibutuhkan kesabaran dan ketekunan para pendidiknya yang harus didukung dengan keseimbangan antara pendidikan orang tua di rumah dengan pendidikan di sekolah (Ainissyifa, 2014: 3). Prasetyo (2011: 8-14) menjelaskan bahwa ada dua faktor yang mempengaruhi pembantukan karakter, yaitu bawaan dari dalam diri anak dan pandangan anak terhadap dunia yang dimilikinya, seperti pengetahuan, pengalaman, prinsip-prinsip moral yang diterima, bimbingan, pengarahan dan interaksi (hubungan) orang tua anak. Proses pembentukan karakter diawali dengan kondisi pribadi ibu-ayah sebagai figur yang berpengaruh untuk menjadi panutan, keteladanan, dan diidolakan atau ditiru anak-anak. Sikap dan perilaku ibu-ayah sehari-hari merupakan pendidikan watak yang terjadi secara berkelanjutan, terus-menerus dalam perjalanan umur anak.

Pemahaman masyarakat tentang parenting masih kurang. Hal ini dapat dilihat dari kurangnya kesadaran orang tua terhadap pembentukan karakter anak melalui parenting. Kurangnya pemahaman tentang parenting juga terjadi di masyarakat Desa Kauman Sedayu Gresik. Kauman adalah salah satu desa di Sidayu, Kabupaten Gresik yang berada di pusat kota Sidayu yang hanya seluas 4,6 ha. Masyarakat desa Kauman mempunyai perbedaan latar belakang pendidkan yang beragam, mulai dari sekolah dasar sampai perguruan tinggi. Latar belakang pendididikan yang beragam serta mata pencaharian yang beragam mempengaruhi pemahaman masyarakat tentang parenting.

Berdasarkan observasi yang dilakukan tim pengabdi terhadap masyarakat di Desa Kauman, Sedayu, Kabupaten Gresik yaitu terdapat beberapa permasalahan yang dihadapi oleh masyakat yaitu kurangnya pemahaman masyarakat tentang pembentukan karakter anak melalui kegiatan parenting, asumsi yang berkembang dalam masyarakat bahwa pembentukan karakter dan pemberian pendidikan merupakan tanggung jawab 
sekolah (Hal ini terjadi karena sebagian besar kegiatan anak dilakukan di sekolah), kurangnya pemahaman peranan keluarga dalam peningkatan pendidikan anak, latar belakang pendidikan orang tua yang beragam yang mempengaruhi pembentukan karakter anak, kurang maksimalnya peran orang tua dalam peningkatan kualitas pendidikan anak.

Pemahaman tentang parenting untuk pembentukan karakter anak dalam sebuah keluarga sangatlah penting. Karena keluarga adalah unit terkecil dari masyarakat. Berdasarkan permasalahan diatas maka perlua adanya kegiatan pelatihan yang dikemas dalam pengabdian kepada masyarakat yang nantinya memberikan pengetahuan materi yang berkaitan dengan pembentukan karakter anak melalui pelatihan parenting di Desa Kauman, Sedayu, Gresik

\section{Metode}

Metode yang akan digunakan untuk menyelesaikan kegiatan ini yaitu metode Ceramah dengan menampilkan media Audio visual dan demonstrasi. Kegiatan yang akan dilakukan dengan memberikan penjelasan dan paparan tentang pembentukan karakter anak melalui kegiatan parenting dengan hal yang menyertainya. Pelaksanaanya akan terbagi mejadi 3 (tiga) tahapan yaitu; (1) persiapan PPM, (2) pelaksaan PPM, (3) evalusasi PPM.

1. Persiapan PPM

pada tahapan ini tim PPM melakukan identifikasi hal-hal yang akan dilaksanakan dalam sebuah kegiatan PPM, diantaranya:

a. Melaksanakan kunjungan awal ke mitra

b. Menentukan metode kegiatan PPM

c. hasil identifikasi, selanjutnya mendapat memetakan langkah dan apa saja yang akan diperlukan.

2. Pelaksanaan PPM

Kegiatan PPM parenting di Desa Kauman Sedayu Gresik dimulai dengan memberikan pre test, hal ini bertujuan mengetahui pemahaman awal peserta tentang parenting. Selanjutnya kegiatan dilakukan dengan menyampaikan materi kegiatan parenting dari beberapa narasumber tim dosen PPKn tentang parenting terhadap peserta. Kegiatan pelaksanaan pelatihan tesebut mengacu pada desain pre test post test design (Sugiyono, 2015).

3. Evaluasi

Pada bagian akhir kegiatan peserta kembali diberikan soal post test, ini bertujuan mengetahui keberhasilan kegiatan yang sudah dilakukan, apakah peserta memahami terhadap materi yang sudah dijelasakan oleh narasumber/tim PPM, selanjutnya ini dimaksudkan untuk memberikan feedback kepada TIM PPM dan peserta pelatihan.

\section{Hasil dan Pembahasan}

Kegiatan PPM ini diharapkan memberikan wawasan bagi orang tua, masyarakat terkait dengan pentingnya pembentukan karakter anak melalui kegiatan parenting. Berdasarkan hasil Pre test dengan 10 soal yang kami berikan pada peserta sebelum pelatihan didapatkan data berikut ini: 
Tabel 1. Data hasil Pre Test

\begin{tabular}{clc}
\hline Skor Pemahaman tentang parenting & Kategori & Jumlah Peserta Pelatihan \\
\hline $80<x \leq 100$ & Baik & 8 \\
$65<x \leq 80$ & Sedang & 9 \\
$x \leq 65$ & Kurang & 20 \\
\hline
\end{tabular}

Berdasarkan tabel hasil pre test tersebut diketahui bahwa, hanya 8 peserta dari 37 peserta berada dalam kategori pemahaman yang baik tentang pembentukan karakter anak melalui kegiatan parenting. Hal ini dapat diartikan bahwa sebanyak $21 \%$ dari peserta pelatihan yang memahami hakikat dari parenting.

Setalah diadakan pre test, diadakan pelatihan tentang pembentukan karakter anak melalui kegiatan parenting. Pelatihan dilakukan dengan metode ceramah dengan menampilkan media audio visual dan demonstrasi. Kegiatan yang akan dilakukan dengan memberikan penjelasan dan paparan tentang pembentukan karakter anak melalui kegiatan parenting dengan hal yang menyertainya. Setelah dilaksanakan pelatihan, pemahaman masyarakat mengalami peningkatan. Hal ini dibuktikan dengan nilai post tes yang kami berikan di akhir kegiatan menunjukkan hasil yang memuaskan. Dari 37 peserta yang mengikuti kegiatan ini dan kami beri post tes, sejumlah 29 peserta berada dalam karegori pemahaman yang baik. Hal ini berarti $78 \%$ peserta memahami pembentukan karakter anak melalui kegiatan parenting. Berikut ini tabel hasil post test peserta pelatihan.

Tabel 2. Hasil post test peserta pelatihan

\begin{tabular}{clc}
\hline Skor Pemahaman tentang parenting & Kategori & Jumlah Peserta Pelatihan \\
\hline $80<x \leq 100$ & Baik & 29 \\
$65<x \leq 80$ & Sedang & 5 \\
$x \leq 65$ & Kurang & 3 \\
\hline
\end{tabular}

Berdasarkan hasil kegiatan pelatihan ini dapat disimpulkan bahwa orang tua, masyarakat dan pemerintah desa mempunyai peranan masing-masing dalam kegiatan parenting di lingkungan mereka. Proses pembentukan karakter anak usia dini juga meliputi faktor keluarga, sekolah, dan komunitas. Ketika berbicara mengenai pembentukan karakter anak usia dini, kita menjadi teringat pada faktor lingkungan dan keluarga yang berada dekat dengan anak tersebut. Proses pembentukan karakter diawali dengan kondisi pribadi ibu-ayah sebagai figur yang berpengaruh untuk menjadi panutan, keteladanan, dan diidolakan atau ditiru anak-anak. Sikap dan perilaku ibu-ayah sehari-hari merupakan pendidikan watak yang terjadi secara berkelanjutan, terus-menerus dalam perjalanan umur anak.

Secara garis besar hasil kegiatan pelatihan ini dapat disimpulkan bahwa terdapat hasil atau tambahan pemahaman masyarakat Desa Kauman Kabupaten Gresik Kecamatan Sedayu Gresik tentang pembentukan karakter anak melalui kegiatan parenting. 


\section{Kesimpulan}

Berdasarkan hasil kegiatan pengabdian dalam rangka pembentukan karakter anak melalui kegiatan parenting Melalui Pelatihan Parenting di Desa Kauman Kecamatan Sedayu Kabupaten Gresik didapatkan bahwa terdapat peningkatan pemahaman tentang pembentukan karakter anak melalui kegiatan parenting pada masyarakat Di Desa Kauman Kecamatan Sedayu Kabupaten Gresik. Hal ini terlihat pada saat pre test. Pada saat pre test didapatkan hasil bahwa 8 peserta dari 37 peserta berada dalam kategori pemahaman yang baik tentang hakikat dari parenting, apa fungsi dan tujuan dilaksanakan parenting. Atau dapat diartikan sebanyak $21 \%$ dari peserta pelatihan yang memahami pembentukan karakter anak melalui kegiatan parenting. Sedangkan pada saat post test didapatkan hasil bahwa 29 dari 37 peserta berada dalam karegori pemahaman yang baik. Hal ini berarti $78 \%$ peserta memahami dan mengerti pembentukan karakter anak melalui kegiatan parenting berdasarkan materi yang sudah disampaikan narasumber.

\section{Daftar Pustaka}

A, Tafsir, dkk. 2002. Ilmu Pendidikan Dalam Perspektif Islam. Bandung: PT Remaja Rosdakarya

D. Prasanti, D.R. Fitriani. (2018). Pembentukan Karakter Anak Usia Dini: Keluarga, Sekolah, Dan Komunitas? (Studi Kualitatif tentang Pembentukan Karakter Anak Usia Dini Melalui Keluarga, Sekolah, dan Komunitas). Jurnal Obsesi : Jurnal Pendidikan Anak Usia Dini. Vol 2 (1). Page 13 - 19

H. Ainissyifa. (2014) Pendidikan Karakter Dalam Perspektif Pendidikan Islam. Jurnal Pendidikan Universitas Garut Fakultas Pendidikan Islam dan Keguruan, Vol. 08 N0. 01 Hal. 1-26 ISSN 1907-932X.

Jhonson, C.L. (1988). Ex Familia. New Brunswick: Rutger University Press

Lestari, P. (2008). Pola Asuh Anak Dalam Keluarga ( Studi kasus pada pengamen anakanak di kampung Jlagran, Yogyakarta ). Dimensia, Volume 2 (1), 51-76

M. Arifuddin. (2009) Duhai Anakku; Mendidik Anak Agar Tidak Durhaka. Sidoharjo : Masmedia Buana Pustaka.

Maksudin. 2013. Pendidikan Karakter Non Dikotomik. Yogyakarta : Pustaka Pelajar

N. Prasetyo. (2011). Seri Bacaan Orang Tua: Membangun Karakter Anak Usia Dini. Direktorat Pembinaan Pendidikan Anak Usia Dini

Zainal Aqib. 2011. Pendidikan Karakter; Membangun Perilaku Positif Anak Bangsa. Bandung : Yrama Widya 